Article

\title{
Land Investments, Food Systems Change and Democracy in Kenya and Mozambique
}

\author{
Koen Dekeyser \\ DST-NRF Centre of Excellence in Food Security and Centre for the Study of Governance Innovation, University of Pretoria, \\ 0028 Pretoria, South Africa; E-Mail: koen.dekeyser@governanceinnovation.org
}

Submitted: 22 March 2019 | Accepted: 9 July 2019 | Published: 28 October 2019

\begin{abstract}
In Africa, food systems intersect with dynamics such as demographic growth, urbanisation, and climate change, as African food systems are key drivers of livelihood provision, development, and human-environment interactions. The governance of African food systems shapes how food systems are changing as a response to these dynamics, which will have important social, economic, and ecological impacts for generations of Africans. This article positions large land investments in food system changes in central Kenya and northern Mozambique based on a large-scale household survey and interviews, and uses these findings to debate the concept of food democracy. Large land investments contributed to more modern food systems, which impacted land availability, household's engagement in agriculture, and supply chains. These changes shifted power and control in local food systems. But even in the 'extreme' example of land investments, local perspectives challenge what could, and could not, be included in a democratic food system.
\end{abstract}

\section{Keywords}

food democracy; food systems; Kenya; land investments; large agricultural investments; Mozambique

\section{Issue}

This article is part of the issue "New Perspectives on Food Democracy" edited by Basil Bornemann (University of Basel, Switzerland) and Sabine Weiland (Université Catholique de Lille, France).

(C) 2019 by the author; licensee Cogitatio (Lisbon, Portugal). This article is licensed under a Creative Commons Attribution 4.0 International License (CC BY).

\section{Introduction}

In Africa, food systems intersect with challenges such as demographic growth, urbanisation, and climate change, as African food systems are key drivers of livelihood provision, development, and human-environment interactions. The governance of African food systems shapes how food systems are changing as a response to these challenges, which will have important social, economic, and ecological impacts for generations of Africans. Today, there are strong debates regarding different food governance approaches, each with varying degrees of inclusion and participation, that are likely to result in different food systems. Examples of such food governance debates include food sovereignty and food democracy.

Conventional food governance approaches implicitly contribute to shifts of Africa's 'traditional' food systems to more Western and 'modern' food systems. In traditional food systems, the population engaged in agriculture is high, food production is mostly smallscale and low on external inputs, food distribution is mostly through informal chains, and malnutrition is mostly undernourishment and undernutrition. In modern food systems, most food production is energy and input-intensive, and labour-extensive, while supermarkets have more market share, and overweight and obesity are widespread (Drewnowski \& Popkin, 2009; High Level Panel of Experts on Food Security and Nutrition [HLPE], 2017). Shifting from traditional to modern food systems comes not only with wide-ranging economic, social, and ecological impacts, but also with changed power relations between food system actors.

An example of this conventional approach, and one of the most contentious topics in African food systems, is the phenomenon of Large Agricultural Investments (LAls), popularised as 'land grabs.' The LAls involve acquisitions of land rights, mostly in developing countries, which has caused debates concerning the advantages 
and disadvantages for local communities. While considerable concern was raised concerning the LAI's impact on land, livelihoods, and environment, scant evidence exists on their effects on the structure of the local food systems and the control of local people (Di Matteo \& Schoneveld, 2016; Li, 2011; Oberlack, Tejada, Messerli, Rist, \& Giger, 2016). The LAls phenomenon fits a modernistic development trajectory characterised by largescale monoculture and internationally traded products, and can be a strong driver of local food system change (Borras \& Franco, 2012). As LAls are perceived to modernise the local food systems, they provide a unique opportunity to add empirical findings to discuss the conventional approach to food system change. Furthermore, these empirical findings can be used to reflect on the food governance arrangements, such as food democracy, best suited to respond to dynamics such as demographic growth, urbanisation, and climate change.

In this regard, this article aims to position the concept of food democracy in food system changes in central Kenya and northern Mozambique through the case of LAls. Based on the analysis of large-scale household surveys and interviews, the following research questions were answered: (1) To what extent, and how, were the food systems of households different, and does the difference relate to the presence of LAls?; (2) What were the implications for food democracy of those changes? The overall goal was to provide evidence on the direct and indirect impacts of LAls on food systems in central Kenya and northern Mozambique, and use food democracy to reflect on these changes. In turn, this reflection will show the limitations of food democracy.

The article is structured as follows: Section 2 discusses food democracy, food systems change and land investments in Africa. Section 3 describes the conceptual framework, introduces the study areas, and clarifies the data collection procedures. Section 4 presents data of land investments' impact on the studied food systems in Kenya and Mozambique, and discusses the implications for food democracy. Section 5 concludes with recommendations for future research.

\section{Food Democracy, Systems Change and Land Investments}

\subsection{Food Democracy and Systems Change}

In the 1990s, Tim Lang coined the term 'food democracy' as a response to the perceived concentration of power and control in food systems by 'Big Food' corporations (Booth \& Coveney, 2015), especially in the mid-stream (Reardon, 2015). Food democracy presents an alternative food governance framework centred on societies, communities, and citizens (Goodman, 2014; Hassanein, 2003). At its core, food democracy is:

The idea that people can and should be actively participating in shaping the food system, rather than remaining passive spectators on the sidelines. In other words, food democracy is about citizens having the power to determine agro-food policies and practices locally, regionally, nationally, and globally. (Hassanein, 2003, p. 79)

Thus, food democracy is a process where people regain control and participate (Booth \& Coveney, 2015), with a key role for local spaces (Perrett \& Jackson, 2015).

Authors on food democracy identified drivers that led to the loss of control and participation and projected how a more democratic food system would look. Control and participation are declining due to increasing corporate control, limited information to consumers, the dominance of supermarkets, and convenient food products that replace traditional food (Hassanein, 2008). A democratic food system would resist big food corporations and ultra-processed foods, reject genetically modified organisms, produce through sustainable methods, and reconnect producers and consumers (Booth \& Coveney, 2015; Hassanein, 2008; Lang, 2005; Levkoe, 2006). Examples of food democracy include community-supported agriculture and local food councils (Hassanein, 2003; Johnston, Biro, \& MacKendrick, 2009).

Food democracy is not the only alternative food governance framework that emerged from the 1990s. Although overlapping, food democracy and food sovereignty differ in program and grassroots base. Unlike food democracy, food sovereignty has a program that is strongly focused on agrarian reform, which is partly adopted in legislation of countries such as Bolivia, Mali, and Nepal (Schiavoni, 2017). Food sovereignty has strong grassroots movements, and origins, in the developing world (Edelman, 2014), which results in more emphasis on 'traditional' food systems compared to food democracy. A pan-African food sovereignty alliance is supplemented by national food sovereignty movements, whereas food democracy lacks term recognition and a popular movement in Africa. Now, food sovereignty is challenged for its ambiguity and applicability in more pluralistic, complex, and less rural societies and food systems (Dekeyser, Korsten, \& Fioramonti, 2018). The increased complexity of African food systems encourages more attention to food democracy for the analysis of power and control, as citizens' control and participation are more easier to enact than food sovereignty.

In Africa, societies and food systems are transforming towards increased pluralism and complexity. African societies are changing rapidly through demographic changes, economic growth, and climate change (Christiaensen, 2017). The 'traditional' food systems are under pressure from an inroad of supermarkets, land investments, and urbanisation (Gómez \& Ricketts, 2013). These pressures result in many food system changes, including shifting malnutrition, more food purchases, and more land competition (HLPE, 2017; May, 2018). Generally, 'traditional' food systems are changing towards more 'modern' food systems (HLPE, 2017). Lang (2005) provides a spectrum 
of the modern food system, where one side is 'food control,' with long-distance trade and large farms, and the other side is 'food democracy,' with local trade and small farms. The food control side has lower citizen's control and participation than the food democracy side, in part because of differences in large versus small farms, longdistance food versus local food, hypermarkets versus street markets, and dominance of sugar and fat-dense diets versus nutrient-diverse diets.

It is unlikely that the transition from traditional to modern is linear and uniform, and that citizens' control automatically decreases. For example, Abrahams (2009) found the growth of traditional food distribution alongside a developing modern distribution in Zambia, while policymakers included more farmers into their food distribution policies in Uganda. The aggregated statistics on food systems change rarely capture these competing $d y-$ namics (van der Ploeg, 2018). Thus, case studies can provide needed empirical validation on food systems change.

\subsection{Land Investments}

One of the most contentious topics of change, power and control in African food system is the LAl phenomenon, popularised through the term 'land grabs.' The term LAls better capture the complexities of the current surge in agri-investments than land grabs (Hall, 2011). Within the wave of LAls, land rights for more than 42.2 million ha worldwide were transferred between 2000 and 2016 (Nolte, Chamberlain, Giger, \& Wilson, 2016), which is a much higher rate of land transfer than those in the past decades (Deininger, 2011). In this article, the LAls are not only 'transfers of rights to use, control, or own land from smallholder households or communities to corporate actors...through sale, lease, or concession of areas larger than 200 ha' (Oberlack et al., 2016, p. 154), but also refer to the size of capital investment and labour employed (Zaehringer, Wambugu, Kiteme, \& Eckert, 2018).

A transfer of ownership is rare; most of these land deals are leases with a duration that is up to 50 or 99 years (Cotula, 2013). Land investment in Africa is driven by the large amount of perceived available land and weak land rights (Deininger, 2011), increased demand and prices for food, energy systems transitions, biodiversity conservation, climate change responses, geopolitics and development strategies (Oberlack et al., 2016). In Africa, LAls drive specific land-use change, which can shift food crops for self-consumption to cash crops, food crops to biofuels, or convert non-food lands such as forests to food production or biofuels (Borras \& Franco, 2012). The LAls are associated with business models that range from independent farmers, cooperatives, 1000-day speculative farming, asset management, contracting, and agribusiness models (Boche \& Anseeuw, 2013). These business models are 'frequently associated with industrial agricultural production methods, dominated by transnational corporations producing for export' (Clapp, 2015, p. 307). The primary types of investor worldwide and in Africa are private companies (45\% of total area worldwide) and stock exchange-listed companies (32\%; Nolte et al., 2016).

Within the LAls debate, proponents argue the opportunities that LAls can bring to local communities and rural development through a greater access to capital, technology, knowledge and markets, while LAls projects can contribute to economic growth and national government revenue (Cotula, Vermeulen, Leonard, \& Keeley, 2009; Deininger \& Xia, 2016). However, whether the recipient countries have the capacity to manage these land deals is doubted (de Schutter, 2011). African land rights are often vague, and local communities might be excluded from the negotiations, which heightens the risk of conflicts between local communities and investors (Cotula et al., 2009). LAls exacerbate existing tensions as they traverse formal, customary, ethnic and historical relationships within changing rural landscapes. For the local communities, who wins and who loses from LAls is differentiated by class, gender, education, age, nationality, and religion. In short:

While, in principle, investments in large production units or higher up in the agricultural value chain can have very positive effects on neighboring small farmers, systematic evidence of the size of such effects remains scant, limiting the scope for evidence-based policy-making. (Deininger \& Xia, 2016, p. 228)

\section{Framework, Material and Methods}

\subsection{Framework}

This article aimes to position the concept of food democracy in food system changes in central Kenya and northern Mozambique through the case of LAls. The change of food systems by LAls is approached through a case study design with a counterfactual group. The dynamic of LAls is used as an 'extreme' case study that could transform local food systems towards more modernity. For this article, there was a focus on the food supply chains, food environments, and dietary shifts (Figure 1). The conceptual framework links LAls with dietary changes through five hypothesised steps. First, the LAls would decrease land availability (i.e., the stock of land that is available in a locality) and access (i.e., household's land access), and provide certain off-farm employment opportunities. Second, the decreased land availability and access, and time taken by off-farm employment, would decrease agri-engagement. Third, decreased agriengagement and time taken by off-farm employment would result in more market dependence for a household's dietary needs. Fourth, in turn, more market integration would lead to more market development. Fifth, as the market would provide different food (e.g., more energy-dense products) than what a household would grow (e.g., more staple crops), the integration and development of markets would lead to dietary changes. 


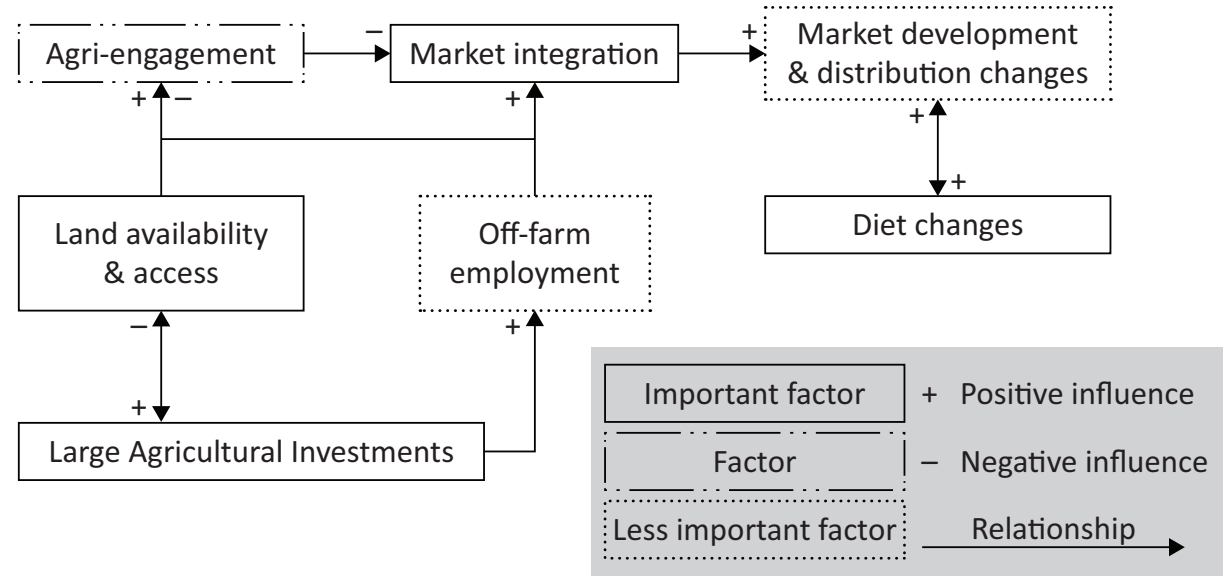

Figure 1. Conceptual framework illustrating hypothesised linkage of large agricultural investments and diet changes.

Food democracy is used to reflect on the changes depicted in Figure 1, which will feed into a discussion on the concept of food democracy. First, Lang's (2005) food democracy conceptualisation, which is characterised by small farms, local food, street markets, and lower prevalence of sugar and fat-dense foods, is used to discuss the shifts in power and control in food systems by LAls. Thus, this part reflects on the changes in food democracy induced by LAls through the prevalence of Lang's characteristics. Second, the assumption that increased citizen power and control will lead to a food system with Lang's characteristics is discussed. The outcome of this reflection examines food democracy as an outcome, exemplified by small farms, local food, street markets, and lower prevalence of sugar and fat-dense foods, and food democracy as a process, where increased citizen's power and control is not linked to a particular food system arrangement.

\subsection{Study Areas}

The study areas were situated around Nanyuki, central Kenya, and in the Gurué and Monapo Districts, northern Mozambique (Figure 2). First, the two countries were selected according to their different LAls dynamics, such as land-extensive or land-intensive, as this is likely to generate different food system changes. Second, the regions and study areas within each country were selected according to their prevalence of LAls.

Kenya has a long-standing tripartite relationship between state, agribusiness, and smallholders (Oya, 2012). The sector is dominated by small-scale farmers that provide $75 \%$ of all outputs, but the average plot is ever decreasing in size (Food and Agriculture Organization of the United Nations [FAO], 2018). Kenya's agricultural sector struggles with shifting weather patterns, population growth, changing demographics, and political instability (D'Alessandro, Caballero, Lichte, \& Simpkin, 2015). While British colonial rule (1895-1963) and its grabbing of land created much landlessness, Kenyan political elites used land redistribution after independence to mobilise communities and to grab land for themselves and their patronage. Land and ethnic linkages are still used for mobilisation (Médard, 2010). The population in Kenya is estimated to double in the next 27 years, pushing the agricultural frontier into more marginal areas and increasing tensions with pastoralists (FAO, 2017). In short, relatively high population densities squeezes land

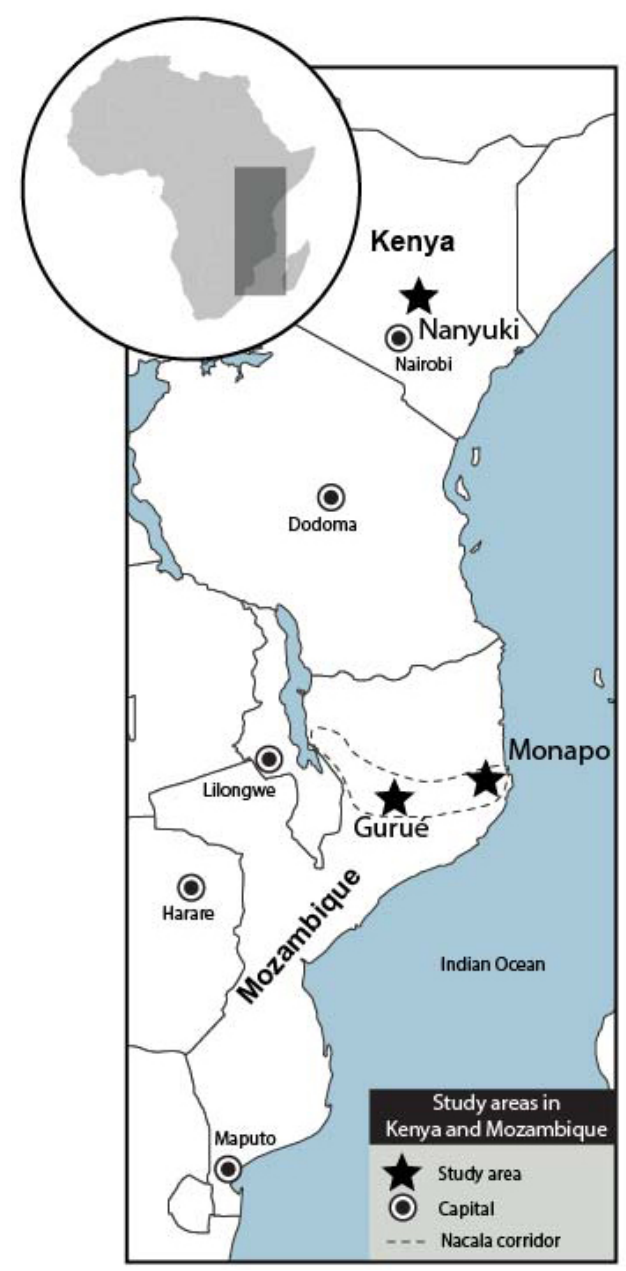

Figure 2. Location of the study areas in Kenya (Nanyuki) and Mozambique (Monapo and Gurué). 
availability, which was already skewed by colonial history and post-colonial patronage. This results in farmers occupying small plots of land that perform under their productive potential and contribute to their poverty trap (Deininger, 2011; Ulrich, 2014).

Kenya's LAI potential is characterised as 'little land available, high yield gap' (Deininger, 2011). Generally, Kenyan elites sell former colonial farms to investors, which does not cause land dispossession, and are thus rarely recorded in international land monitoring initiatives (Klopp \& Lumumba, 2014).

In Kenya, the 'factual' study area, which contains the LAls, stretches from Tigithi along Mount Kenya to Timau, and includes the sub-locations Buuri, Tigithi, Kangaita, Nyaringinu, and Naibor. In this area, large farms are the major employers of the region (Ulrich, 2014). Sources of contention related to the large farms were the sharing of scarce water between small and large farmers, the wage of workers on large farms, and the impacts of the floriculture's extensive use of chemicals on the health of workers and surrounding communities (Lanari, Liniger, \& Kiteme, 2016). The LAls types in these areas include floriculture and horticulture. The counterfactual area was Barrier, which lies approximately $10 \mathrm{~km}$ from the nearest LAI and has similar demographics as the factual areas.

In Mozambique, about $75 \%$ of its 29 million people are involved in agriculture, mostly on small plots. In 2012, $99.8 \%$ of Mozambique's four million farms were between 0.1 and 10 ha, and small-scale farmers occupied $90 \%$ of cultivated land (Oya, 2012). As a result, small-scale farming is crucial for livelihood provision and food security. However, the average small farm shrank between 2002 and 2014 (Deininger \& Xia, 2016). After public consultation, Mozambique adopted in 1997 one of the most progressive land laws in the world. While the state provides formal land rights, customary land rights have full legal equivalence. This provision protects land users in a country with a low degree of formalised title deeds (Cotula et al., 2009). However, practical registration of land rights and enforcement of the land laws are lacking (Tanner, 2010). The Mozambican elites benefit from this lack of implementation to facilitate land dispossession, either for their personal projects or to enable foreign investors to access land (Milgroom, 2015). Mozambique ranks as a top recipient country for LAls (Nolte et al., 2016). The pull factors for land investments in Mozambique include high yield gaps, low population density, and 'plentiful suitable' land (Deininger, 2011).

The first Mozambican study area was situated in the Gurue region, which is located in the Zambezia Province. The factual study area was Manlé town, which is about $15 \mathrm{~km}$ east from Gurué town. Manlé's adjoining tea plantations were established under colonial rule. With the 1990s civil war, the plantation declined, and small-scale farmers worked the unused land. Recently, the company expanded on their former lands and dispossessed the small-scale farmers. The counterfactual town of Muela was situated south of Gurué with no LAls present within $20 \mathrm{~km}$. Muela connected to the main road through a dirt path and had similar demographics as Manlé. The second Mozambican study area was situated in Monapo, which is part of the Nampula Province. The factual study area was Monapo town, which adjoins a former colonial sisal plantation. This plantation ceased activity between 1970 and the 1990s, and small-scale farmers cultivated on the idle land. In 2005, a new company bought the former plantation and expelled the small-scale farmers. The counterfactual site was Canacué town, to the south of Monapo town, which had similar demographics as Ramiane.

\subsection{Data Collection}

The data were collected between February 2016 and March 2017 through a livelihood and food security survey, which was approached differently in the two countries. In Kenya, stratified random sampling selected 488 heads of households, while in Mozambique random sampling selected 376 heads of households (Table 1). In the Kenyan study region, five sub-locations (Buuri, Tigithi, Kangaita, Nyaringinu, and Naibor) around a LAI were selected to represent the business types of LAls in these areas. Within these areas, 318 households were randomly selected. Another sub-location, Barrier, was selected as a counterfactual area, and 170 households were randomly selected. For each household, a weight was attributed to each household proportionally to the total number of households of the sub-location. As a result, the analysis is representative of the whole studied region (Reys et al., 2018). When weighted, the Kenyan survey represented 6692 households. In Mozambique, two regions were chosen to capture different business models

Table 1. Characteristics of cases and the number of completed household surveys, by category.

\begin{tabular}{llll}
\hline & Case 1 & Case 2 & Case 3 \\
\hline Country & Kenya & Mozambique & Mozambique \\
Region & Nanyuki & Gurué & Monapo \\
Households per category (total) $_{\text {Employed (E) }}^{\mathrm{a}}$ & $(488)$ & $(169)$ & $(207)$ \\
Non-engaged (NE) $^{\mathrm{a}}$ & $48^{\mathrm{b}, \mathrm{c}}$ & 37 & 60 \\
Counterfactual (CF) $^{\mathrm{b}}$ & $270^{\mathrm{b}, \mathrm{c}}$ & 22 & 29 \\
\hline
\end{tabular}

Notes: ${ }^{\text {a }}$ LAl area; ${ }^{\text {b }}$ Weigthed; ${ }^{\mathrm{c}}$ Aggregated. Source: Afgroland $(2016,2017)$. 
and agro-ecological conditions. In both regions, a factual and counterfactual sub-location were chosen and households randomly selected (Reys, 2016). The households of the Gurué and Monapo regions were not weighted because of the agro-ecological heterogeneity of the different regions.

In both countries, the households within a LAI area were categorised as 'Employed' (E) if minimally one household member worked at a LAI and categorised as 'Non-engaged' (NE) when no-one was employed by a LAI. The households in the counterfactual areas were categorised as 'Counterfactual' (CF). In Kenya, the employed and non-engaged categories were aggregated across the sub-locations. In each country, enumerator teams consisted of trained nationals. The enumerators selected the household closest to each random point and invited the head of the household, or if absent the spouse, for an interview. If both the households' head and spouse were absent, the enumerators moved to the next closest household. This survey was complemented with interviews of actors in the distribution system, decisionmakers, and civil society actors. The research design is between-groups analysis, which focuses on examining differences between groups.

\section{Results and Discussion}

\subsection{General Characteristics of the Households}

In Kenya, the average household had 4.2 ( \pm 2 ) members with a median age of 24 years, and $22.7 \%$ were female-headed. Most households (75.7\%) migrated from a nearby area, 9.9\% migrated from far away, and only $14 \%$ originated from the study area. More households in the LAl area were immigrants compared to the CF area. The main reason for migration was land $(80.6 \%)$, followed by work (12.3\%), and family (6.3\%). In the LAl area, work was more important, and land less, for migration compared to the CF area. The main annual crops grown were maize, potato, wheat, and beans. In Mozambique, the average household had 4.7 ( \pm 2 ) members with a median age of 15 years old, and $12.2 \%$ were female-headed. Most households originated from the area (55.9\%), $14.9 \%$ migrated from nearby, and $29.3 \%$ migrated from far away. The family was the main reason for migration (64.7\%), followed by work (25.7\%), and family (7.4\%). In both cases, migration to the LAI areas was more driven by work, and land less, compared to the CF areas. In Case 2, the LAl area had a similar proportion of migrants than the CF area, but in Case 3 the LAI area had more migrants. The main annual crops grown were manioc, maize, beans, and sorghum.

\subsection{Food System Changes}

The key households' statements and characteristics are presented by case and household's category in Table 2 . Overall, the effects of LAI differed by country, case, and category. Notably, other pressures besides LAls, such as economic development and demographic growth, were prevalent in the study areas. However, depending on the case, there were indications that LAls impacted land access and availability, migration, agri-engagement, food distribution channels, and food environments. Generally, while traditional dynamics thrived, the households in the LAl areas were more part of a 'modern' food systems than CF areas.

The effects of LAls on land differed according to the case's country. Between $96.6 \%$ and $100 \%$ of Kenyan and Mozambican households had access to land, and the total land size per household was generally higher in the CF areas compared to the LAI areas. In Kenya, LAls had more impact on land access than availability, while in Mozambique, this was the opposite. In Kenya, no LAI caused direct land dispossession, but $48.1 \%$ of households in the factual area perceived the LAls as negatively impacting land availability. In Mozambique, the LAls dispossessed $26.6 \%$ of households in the factual areas of land. In both Mozambican cases, land dispossession was lower for those households that worked at the farms. In interviews, employees of the LAls indicated an arrangement to continue farming on another part of the LAl's land, while non-employees were expelled. None of the dispossessed households received compensation. Interestingly, $69.4 \%$ of households in the factual areas did not perceive the LAls as impacting land availability, which suggests that, while Mozambican LAls evict smallscale farmers of the land, other stocks of land was available for farmers.

Overall, Kenya's CF area had less agri-engagement than the LAl area, which was the reverse in Mozambique. In Kenya, interviewees indicated that youth worked at LAls to raise capital for their own farms. As a result, the CF area had fewer increases in agri-engagement because its youth lacked this opportunity for capital access. In Mozambique, agricultural disengagement was lower in CF areas ( $0.9 \%$ to $4.2 \%)$ than LAl areas (9.1\% to $30 \%)$, possibly because of higher land dispossession and employment opportunities by the LAls. In Kenya, animal ownership was high (89.5\% to 94.1\%) for all categories, while Mozambican ownership varied considerably by category, but was higher in Case 2 than Case 3. In Kenya and Mozambique, most of the annual produce grown was kept for self-consumption. However, diets were more sourced from food purchases, such as markets and shops, than self-production. None sold to supermarkets, although few households sold their crops to agribusinesses in Kenya ( $0 \%$ to $2.9 \%$ ). In Kenya, most of the sales were to middlemen, with few households that sold directly to markets. The households with a LAI employee kept least of their produce and sold most, while the CF area produced more for the diets. In Mozambique, the CF areas sold more of their produce compared to the LAI areas. Overall, the markets, rather than the middlemen, were the most important channels of sale. The diets in the CF area were more derived from self-production than the 


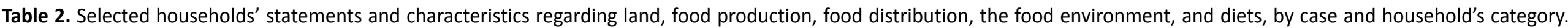
Values indicate the percentage of households unless indicated otherwise.

\begin{tabular}{|c|c|c|c|c|c|c|c|c|c|}
\hline & \multicolumn{3}{|c|}{ Case $1^{a}$} & \multicolumn{3}{|c|}{ Case 2} & \multicolumn{3}{|c|}{ Case 3} \\
\hline & $\mathbf{E}$ & NE & CF & $\mathbf{E}$ & NE & CF & $\mathbf{E}$ & NE & CF \\
\hline Land & $(\mathrm{N}=956)$ & $(N=5056)$ & $(N=680)$ & $(n=37)$ & $(n=22)$ & $(n=100)$ & $(n=60)$ & $(n=29)$ & $(n=118)$ \\
\hline HHs with land access & 100 & 98.5 & 99.4 & 97.3 & 100 & 98.2 & 96.7 & 96.6 & 100 \\
\hline Total land size & $(\mathrm{N}=956)$ & $(N=5056)$ & $(N=680)$ & $(n=37)$ & $(n=22)$ & $(n=100)$ & $(n=60)$ & $(n=29)$ & $(n=118)$ \\
\hline Mean (ha) & 0.8 & 1.1 & 1.6 & 1.9 & 2.4 & 2.4 & 1.7 & 1.9 & 2.4 \\
\hline SD & 0.7 & 1.4 & 1.7 & 1.8 & 2.4 & 2.6 & 1.7 & 1.7 & 2.1 \\
\hline Land loss by LAls & $(\mathrm{N}=956)$ & $(N=5056)$ & $(N=680)$ & $(n=36)$ & $(n=22)$ & $(n=110)$ & $(n=60)$ & $(n=29)$ & $(n=118)$ \\
\hline$\%$ of $\mathrm{HHs}$ & 0.0 & 0.0 & 0.0 & 16.2 & 31.8 & 0.0 & 23.3 & 41.4 & 0.0 \\
\hline \% of HHs reporting a perception & $(\mathrm{N}=956)$ & $(n=5056)$ & $(N=680)$ & $(n=36)$ & $(n=22)$ & $(n=110)$ & $(n=60)$ & $(n=29)$ & $(n=118)$ \\
\hline ...that LAls reduce available land & 57.9 & 46.3 & 9.4 & 30.6 & 36.4 & 1.8 & 25.0 & 37.9 & 0.8 \\
\hline \multicolumn{10}{|l|}{ Food production } \\
\hline \multicolumn{10}{|l|}{ Agri-engagement } \\
\hline over ten years & $(N=956)$ & $(\mathrm{N}=4996)$ & $(N=680)$ & $(n=36)$ & $(n=22)$ & $(n=110)$ & $(n=60)$ & $(n=29)$ & $(n=118)$ \\
\hline More & 10.4 & 4.7 & 7.1 & 0.0 & 9.1 & 3.6 & 5.0 & 3.4 & 1.7 \\
\hline Less & 6.0 & 14.1 & 22.9 & 19.4 & 9.1 & 0.9 & 30.0 & 27.6 & 4.2 \\
\hline \multirow[t]{2}{*}{ Animal ownership } & $(\mathrm{N}=956)$ & $(N=4996)$ & $(N=680)$ & $(n=37)$ & $(n=22)$ & $(n=110)$ & $(n=60)$ & $(n=29)$ & $(n=118)$ \\
\hline & 91.6 & 89.5 & 94.1 & 54.1 & 18.2 & 58.2 & 23.3 & 31.0 & 32.2 \\
\hline \multicolumn{10}{|l|}{ Food distribution } \\
\hline Main sale channels for produce ${ }^{b}$ & $(n=1419)$ & $(n=6885)$ & $(n=960)$ & $(n=115)$ & $(n=81)$ & $(n=397)$ & $(n=136)$ & $(n=65)$ & $(n=340)$ \\
\hline Middlemen & 43.6 & 31.6 & 33.4 & 1.1 & 0.0 & 5.9 & 7.0 & 0.0 & 10.7 \\
\hline No sale & 43.3 & 61.0 & 51.5 & 81.1 & 86.2 & 56.8 & 51.2 & 82.2 & 42.8 \\
\hline Markets & 4.6 & 1.9 & 3.3 & 9.5 & 10.3 & 25.2 & 21.713 .3 & 32.4 & \\
\hline Agribusiness & 2.9 & 0.0 & 0.7 & 0.0 & 0.0 & 0.0 & 0.0 & 0.0 & 0.0 \\
\hline Other & 5.6 & 5.5 & 11.1 & 8.3 & 3.5 & 12.1 & 20.1 & 4.5 & 14.1 \\
\hline Channels to obtain food groups & $(N=956)$ & $(\mathrm{N}=5014)$ & $(N=680)$ & $(n=37)$ & $(n=22)$ & $(n=110)$ & $(n=60)$ & $(n=29)$ & $(n=118)$ \\
\hline Self-production & 20.2 & 18.9 & 29.5 & 29.1 & 32.1 & 37.0 & 19.6 & 20.0 & 28.0 \\
\hline Markets & 42.5 & 44.3 & 38.9 & 40.2 & 36.4 & 28.9 & 55.4 & 56.5 & 46.9 \\
\hline Shop & 33.7 & 34.8 & 29.9 & 4.7 & 4.5 & 5.7 & 0.8 & 0.0 & 1.5 \\
\hline Other & 3.6 & 2.0 & 1.8 & 26.0 & 27.0 & 28.4 & 24.2 & 23.5 & 23.6 \\
\hline
\end{tabular}


Table 2. (Cont.) Selected households' statements and characteristics regarding land, food production, food distribution, the food environment, and diets, by case and household's category. Values indicate the percentage of households unless indicated otherwise.

\begin{tabular}{|c|c|c|c|c|c|c|c|c|c|}
\hline & \multicolumn{3}{|c|}{ Case $1^{a}$} & \multicolumn{3}{|c|}{ Case 2} & \multicolumn{3}{|c|}{ Case 3} \\
\hline & $\mathbf{E}$ & NE & CF & $\mathbf{E}$ & NE & CF & $\mathbf{E}$ & NE & CF \\
\hline \multicolumn{10}{|l|}{ Food environment } \\
\hline Distance to agri-lands & $(N=956)$ & $(\mathrm{N}=4949)$ & $(\mathrm{N}=676)$ & $(n=34)$ & $(n=21)$ & $(n=108)$ & $(n=58)$ & $(n=28)$ & $(n=118)$ \\
\hline With the house & 96.9 & 95.5 & 95.3 & 55.9 & 57.1 & 63.0 & 65.5 & 57.1 & 64.4 \\
\hline$<30 \min$ & 0.0 & 1.7 & 3.6 & 26.5 & 9.5 & 17.6 & 8.6 & 14.3 & 5.1 \\
\hline$>1$ hour & 3.1 & 0.2 & 1.2 & 5.9 & 14.3 & 9.3 & 17.2 & 14.3 & 14.4 \\
\hline Distance to markets & $(\mathrm{N}=956)$ & $(N=5037)$ & $(N=680)$ & $(n=36)$ & $(n=22)$ & $(n=110)$ & $(n=60)$ & $(n=29)$ & $(n=119)$ \\
\hline$<30 \min$ & 34.7 & 17.7 & 15.9 & 24.3 & 22.7 & 0.9 & 60.0 & 62.1 & 71.2 \\
\hline$>1$ hour & 15.2 & 25.8 & 39.4 & 10.8 & 18.2 & 80 & 15.0 & 17.2 & 11.9 \\
\hline FES $^{c}$ & $(\mathrm{~N}=956)$ & $(N=5056)$ & $(N=680)$ & $(n=35)$ & $(n=22)$ & $(n=110)$ & $(n=60)$ & $(n=29)$ & $(n=118)$ \\
\hline Mean & 43.0 & 42.1 & 39.5 & 73.8 & 85.1 & 85.0 & 80.0 & 82.2 & 85.9 \\
\hline SD & 23.7 & 22.3 & 24.0 & 24.6 & 10.6 & 15.6 & 22.9 & 19.1 & 12.8 \\
\hline \multicolumn{10}{|l|}{ Share of self-production in FES } \\
\hline Mean & 24.1 & 23.5 & 35.9 & 56.3 & 63.5 & 69.1 & 43.7 & 51.1 & 58.7 \\
\hline SD & 16.1 & 21.0 & 22.7 & 25.8 & 24.7 & 25.1 & 19.5 & 20.3 & 19.1 \\
\hline \multicolumn{10}{|l|}{ Diets } \\
\hline Days per week consumption of & $(\mathrm{N}=956)$ & $(N=5056)$ & $(\mathrm{N}=680)$ & $(n=37)$ & $(n=22)$ & $(n=110)$ & $(n=60)$ & $(n=29)$ & $(n=118)$ \\
\hline ...Cereals & 5.8 & 6.3 & 6.6 & 4.4 & 4.1 & 4.8 & 4.7 & 4.0 & 3.8 \\
\hline ...Tubers & 4.3 & 4.0 & 4.4 & 4.1 & 4.2 & 3.9 & 3.8 & 4.2 & 4.7 \\
\hline ...Meat & 1.0 & 0.9 & 0.7 & 1.0 & 1.2 & 0.7 & 0.8 & 0.5 & 0.9 \\
\hline ...Oil and fat & 7.0 & 7.0 & 6.8 & 3.3 & 3.4 & 3.0 & 5.1 & 4.4 & 4.4 \\
\hline ...Sweets & 6.0 & 5.8 & 5.6 & 1.9 & 1.6 & 1.2 & 2.4 & 2.3 & 1.5 \\
\hline
\end{tabular}

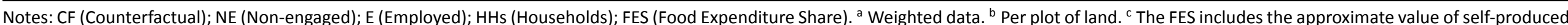
goods that the households consumed in the last 30 days. Source: Afgroland $(2016,2017)$. 
LAI areas, which were more dependent on markets and shops. Case 2 relied less on the markets for their diets than Case 3.

The food environments, particularly the Food Expenditure Share (FES), differed between the cases. In Kenya, about $95 \%$ of the agricultural lands were positioned next to the house, which was maximum $65.5 \%$ in Mozambique. However, Mozambican households had access to more plots than Kenyan households, so dedicated agri-plots were more scattered. The combination of high self-production and close access to agri-lands created a locally-rooted food system configuration, namely producing most of the household diet on a plot near the homestead. In Kenya, the LAI area was closer to markets than the CF area. In Case 2, the CF area was more isolated from markets, as $80 \%$ of the CF area was $>1$ hour away compared to $13.6 \%$ in the LAl areas. In Case 3, the CF was slightly closer to a market than the LAl area.

The share of food expenses in the household's budget-FES-was similar within the countries, which was between $39.5 \%$ to $43 \%$ in Kenya, and $73.8 \%$ to $85.9 \%$ in Mozambique. The high FES of Mozambique showcased the precarious situation of the households, with high vulnerability to either rising food prices, loss of harvest, or declining incomes. In all cases, the CF areas selfproduced more of their food budget than the LAI areas. In Kenya, an average CF household produced $35.9 \%$ of their food budget, compared to $23.6 \%$ in the LAl area. In Case 2, 69.1\% came from self-production in the CF area, compared to $59.1 \%$ in the LAl area. For Case 3, selfproduction contributed to $58.7 \%$ of the CF's area mean food budget and $46.1 \%$ of the LAls. Some food groups were selected to compare diet composition, as particularly higher consumption of meat, oil, fat, and sweets, and lower consumption of cereals and tubers connects with more 'modern' diets (HLPE, 2017). The differences between food group consumption by case and category were minor. The CF areas consumed less oil, fat, and sweets than the LAl areas, but the magnitude of the differences was small. Overall, no categories differed more than one day of consumption per case.

\subsection{Food Democracy between Process and Outcome}

The impacts of LAls on food systems change were complex, context-specific, and operated on a background of other social and economic changes. The analysis shows that the LAls, depending on the case, impacted land access and availability, agri-engagement, food distribution channels, and food environments. This section has two aims: First, to reflect on the changes in food democracy by the prevalence of small farms, local food, street markets, and lower frequency of sugar and fat-dense foods; and second, to discuss if potentially increased local citizen's power and control would counteract these changes or embrace them. This reflection varies due to the heterogeneity of the cases, particularly between the two countries. The LAls did 'modernise' the food sys- tems in which they operated, although competing traditional elements, such as LAI employees that invested in small-scale farming, were as well prevalent. The competing traditional elements illustrate that the modernisation processes were not linear, but hybrid, and results in an unclear picture of how the trajectories of food systems would develop over time. Instead of a linear transition between traditional and modern food systems, a localised hybrid configuration forms with no defined outcome. Agri-policies often overlook the hybridity of food systems, exemplified by 'repeasantisation,' by relying on aggregated statistics (van der Ploeg, 2018).

First, because of historical land relations in the Kenyan study areas, LAls did not directly dispossess households but decreased the amount of available land. The engagement of households in agriculture was stronger in the LAI areas than in the CF areas, which can be driven by a lack of opportunities to raise capital, which LAls can provide. In the last years, several supermarkets opened in the Kenyan study area and more shops were present in the LAI areas. However, all categories obtained most of their diets through self-production and informal markets. These informal markets were a crucial livelihood strategy, as high land prices provided an obstacle to small-scale farming. The differences in energydense food consumption were small. Thus, the changes in Lang's food democratic characteristics were mostly related to land availability and the development of supermarkets. In opposition to Lang's conceptualisation, increased citizen's power and control are unlikely to lead to the removal of LAls, as Zaehringer, Wambugu et al. (2018) found that most interviewed farmers in the study area preferred the LAls to stay. Rather than land, interviewees were displeased with the LAls about competing natural resources, particularly water, low wages, irregular pay, and the difficulty of taking leave. While citizens' participation could improve the employment issues, it is unlikely that most households would favour LAIbased development to dedicated pro-poor investments, such as in small-scale farmer production. Lastly, supermarkets established themselves in the main town, but sold few fresh fruit and vegetables. Outside of town, the informal chains sold supermarket products in the study areas, showcasing a 'modern-to-traditional' value chain (Gómez \& Ricketts, 2013), which diversified food availability and generated employment. However, when supermarkets expand their stock and reach, increased citizen's power is unlikely to allow supermarkets to compete directly with traditional fresh fruit and vegetable markets. Overall, even in the 'extreme' example of LAls, local perspectives challenge what could, and could not, be included in a democratic food system.

Second, in the Mozambican study areas, LAls dispossessed households of land and lowered agri-engagement of households. Self-production was more important for CF areas, and the LAI areas were more dependent on the markets for their dietary needs. Generally, traditional value chains were more present than modern chains, as 
the area lacked supermarkets and almost all the food trade was informal. The differences in energy-dense food consumption were small, but higher than in Kenya. The changes in food democracy characteristics by LAls connect to land, agri-engagement, and market dependence, which were all related to LAI's land dispossessions. As Zaehringer, Atumane et al. (2018) noted, most smallscale farmers around the study areas wanted the LAls to leave. While interviewees were positive about employment generated by LAls, they were displeased about land dispossessions. In this regard, increased citizens' participation could contribute to the removal of LAls and provide a bulwark against land speculation and protect small-scale farmers' agri-engagement. More disadvantages were reported because of the stronger power disparities in Mozambique. Reducing these disparities through citizen's participation can change the balance between disadvantages and advantages of LAls, alike the Kenyan case, where LAls provide more benefits but are unlikely to be a preferred development trajectory.

\section{Conclusion}

This study adds empirical findings to the discussion on LAls' impacts on food systems change and food democracy through case studies in Kenya and Mozambique. This article used Lang's food democracy characteristics to reflect on the food system changes in the study areas, which in turn is used to discuss the concept of food democracy. Particularly, a tension in food democracy as a process of increased citizen's participation, power, and control, and as an outcome related to small farms and local markets is debated. In Kenya, changes include land availability and an influx of supermarkets. Increased citizens' control might not lead to LAl's removal, but better employment and limits on supermarket competition with fresh fruit and vegetable markets. In Mozambique, changes include land availability, agri-engagement, and market dependence. Because of stronger power disparities, more disadvantages were reported in Mozambique, which could lead to the removal of LAI companies when local communities gain more decision-making power. Thus, the outcome of increased food democracy is likely to be different for each case, indicating that even in the 'extreme' example of LAls, local perspectives challenge what could, and could not, be included in a food democratic system. As a result, a process of increased democracy might lead to diverse local food system arrangements which are different from Lang's food democracy. With more power, local actors can better negotiate the advantages and disadvantages of traditional and modern food systems and shape their own local food system trajectory. Given the increased complexity of food systems, this trajectory is then likely to be more hybrid than lineary traditional or modern. In the end, the reflection of food democracy through LAls show its multidimensionality, with food democracy being simultaneously a process, outcome, set of policies, and a norma- tive framework. Future research that starts from the tensions between these dimensions can further clarify and strengthen the concept of food democracy. This is necessary if food democracy is to be used in policy debates in Africa and beyond.

\section{Acknowledgments}

The research for this publication was conducted as part of the BELMONT Forum and FACCEeJPI project "African Food, Agriculture, Land and Natural Resource Dynamics, in the context of global agrofood-energy system changes (AFGROLAND; Grant Number: 40FA40_160405)." The Swiss National Science Foundation, the French National Research Agency, and the South African National Research Foundation funded this project. I am grateful to the respondents and interviewees for their time, and I acknowledge the contribution and support of the principal investigators and field assistants. I thank the DST-NRF CoE in Food Security for funding, the editorial team at Politics and Governance and the anonymous reviewers for helpful comments, and Camilla Adelle for proofreading.

\section{Conflict of Interests}

The author declares no conflict of interests.

\section{References}

Abrahams, C. (2009). Transforming the region: Supermarkets and the local food economy. African Affairs, 109(434), 115-134.

Afgroland. (2016). Mozambique household survey. Unpublished manuscript.

Afgroland. (2017). Kenya household survey. Unpublished manuscript.

Boche, M., \& Anseeuw, W. (2013). Unraveling "land grabbing": Different models of large-scale land acquisition in Southern Africa (Working Paper 46). Rotterdam: LDPI.

Booth, S., \& Coveney, J. (2015). Democracy at work: From consumers to food citizens. Singapore: Springer.

Borras, S. M., \& Franco, J. C. (2012). Global land grabbing and trajectories of agrarian change: A preliminary analysis. Journal of Agrarian Change, 12(1), 34-59.

Christiaensen, L. (2017). Agriculture in Africa. Telling myths from facts: A synthesis. Food Policy, 67, 1-11.

Clapp, J. (2015). Distant agricultural landscapes. Sustainability Science, 10(2), 305-316.

Cotula, L. (2013). The great African land grab? Agricultural investments and the global food system. London: Zed Books.

Cotula, L., Vermeulen, S., Leonard, R., \& Keeley, J. (2009). Land grab or development opportunity? Agricultural investments and international land deals in Africa. London and Rome: IIED, FAO, and IFAD.

D’Alessandro, S. P., Caballero, J., Lichte, J., \& Simpkin, 
S. (2015). Kenya: Agricultural sector risk assessment. Washington, DC: The World Bank.

de Schutter, O. (2011). How not to think of land-grabbing: Three critiques of large-scale investments in farmland. Journal of Peasant Studies, 38(2), 249-279.

Deininger, K. (2011). Challenges posed by the new wave of farmland investment. The Journal of Peasant Studies, 38(2), 217-247.

Deininger, K., \& Xia, F. (2016). Quantifying spillover effects from large land-based investment: The case of Mozambique. World Development, 87, 227-241.

Dekeyser, K., Korsten, L., \& Fioramonti, L. (2018). Food sovereignty: Shifting debates on democratic food governance. Food Security, 10(1), 223-233.

Di Matteo, F., \& Schoneveld, G. C. (2016). Agricultural investments in Mozambique: An analysis of investment trends, business models and social and environmental conduct (Working Paper No. 201). Bogor: Center for International Forestry Research.

Drewnowski, A., \& Popkin, B. M. (2009). The nutrition transition: New trends in the global diet. Nutrition Reviews, 55(2), 31-43.

Edelman, M. (2014). Food sovereignty: Forgotten genealogies and future regulatory challenges. The Journal of Peasant Studies, 41(6), 959-978.

Food and Agriculture Organization of the United Nations. (2017). Country programming framework for Kenya: 2014-2017. Rome: Food and Agriculture Organization of the United Nations.

Food and Agriculture Organization of the United Nations. (2018). Family farming knowledge platform. Food and Agriculture Organization of the United Nations. Retrieved from http://www.fao.org/family-farming/ data-sources/dataportrait/farm-size/en

Gómez, M. I., \& Ricketts, K. D. (2013). Food value chain transformations in developing countries: Selected hypotheses on nutritional implications. Food Policy, 42, 139-150.

Goodman, M. K. (2014). The ecologies of food power: An introduction to the environment and food book symposium. Sociologia Ruralis, 54(1), 94-97.

Hall, R. (2011). Land grabbing in Southern Africa: The many faces of the investor rush. Review of African Political Economy, 38(128), 193-214.

Hassanein, N. (2003). Practicing food democracy: A pragmatic politics of transformation. Journal of Rural Studies, 19(1), 77-86.

Hassanein, N. (2008). Locating food democracy: Theoretical and practical ingredients. Journal of Hunger and Environmental Nutrition, 3(2/3), 286-308.

High Level Panel of Experts on Food Security and Nutrition. (2017). Nutrition and food systems (Report of the Committee on World Food Security). Rome: High Level Panel of Experts on Food Security and Nutrition.

Johnston, J., Biro, A., \& MacKendrick, N. (2009). Lost in the supermarket: The corporate-organic foodscape and the struggle for food democracy. Antipode, 41(3), 509-532.
Klopp, J. M., \& Lumumba, O. (2014). Kenya and the "global land grab": A view from below. In M. Kaag \& A. Zoomers (Eds.), The global land grab: Beyond the hype (pp. 54-68). London: Zed Books.

Lanari, N., Liniger, H., \& Kiteme, B. (2016). Commercial horticulture in Kenya: Adapting to water scarcity (Centre for Development and Environment Policy Brief, No. 8). Bern: Centre for Development and Environment.

Lang, T. (2005). Food control or food democracy? Reengaging nutrition with society and the environment. Public Health Nutrition, 8(6A), 730-737.

Levkoe, C. Z. (2006). Learning democracy through food justice movements. Agriculture and Human Values, 23(1), 89-98.

Li, T. M. (2011). Centering labor in the land grab debate. Journal of Peasant Studies, 38(2), 281-298.

May, J. (2018). Keystones affecting sub-Saharan Africa's prospects for achieving food security through balanced diets. Food Research International, 104, 4-13.

Médard, C. (2010). 'Indigenous' land claims in Kenya: A case study of Chebyuk, Mount Elgon District. In W. Anseeuw \& C. Alden (Eds.), The Struggle over land in Africa: Conflicts, politics \& change (pp. 19-36). Cape Town: HSRC Press.

Milgroom, J. (2015). Policy processes of a land grab: At the interface of politics 'in the air' and politics 'on the ground' in Massingir, Mozambique. The Journal of Peasant Studies, 42(3/4), 585-606.

Nolte, K., Chamberlain, W., Giger, M., \& Wilson, D. (2016). International land deals for agriculture. Fresh insights from the land matrix: Analytical report II. Bern, Montpellier, Hamburg and Pretoria: Centre for Development and Environment-University of Bern, CIRAD, German Institute of Global and Area Studies, University of Pretoria and Bern Open Publishing.

Oberlack, C., Tejada, L., Messerli, P., Rist, S., \& Giger, M. (2016). Sustainable livelihoods in the global land rush? Archetypes of livelihood vulnerability and sustainability potentials. Global Environmental Change, 41, 153-171.

Oya, C. (2012). Contract farming in Sub-Saharan Africa: A survey of approaches, debates and issues. Journal of Agrarian Change, 12(1), 1-33.

Perrett, A., \& Jackson, C. (2015). Local food, food democracy, and food hubs. Journal of Agriculture, Food Systems, and Community Development, 6(1), 7-18.

Reardon, T. (2015). The hidden middle: The quiet revolution in the midstream of agrifood value chains in developing countries. Oxford Review of Economic Policy, 31(1), 45-63.

Reys, A. (2016). Mozambique: Sample and survey method. Unpublished manuscript.

Reys, A., Anseeuw, W., Burnod, P., Kiteme, B., Mercandalli, S., Mutea, E., \& Giger, M. (2018). Large-scale agriculture investments in Central Kenya: Impacts on livelihoods and rural development. Unpublished manuscript. 
Schiavoni, C. M. (2017). The contested terrain of food sovereignty construction: Toward a historical, relational and interactive approach. The Journal of Peasant Studies, 44(1), 1-32.

Tanner, C. (2010). Land rights and enclosures: Implementing the Mozambican land law in practice. In W. Anseeuw \& C. Alden (Eds.), The struggle over land in Africa: Conflicts, politics \& change (pp. 105-130). Cape Town: HSRC Press.

Ulrich, A. (2014). Export-oriented horticultural production in Laikipia, Kenya: Assessing the implications for rural livelihoods. Sustainability, 6(1), 336-347.

van der Ploeg, J. D. (2018). Differentiation: Old contro- versies, new insights. The Journal of Peasant Studies, 45(3), 489-524.

Zaehringer, J. G., Atumane, A., Berger, S., \& Eckert, S. (2018). Large-scale agricultural investments trigger direct and indirect land use change: New evidence from the Nacala corridor, Mozambique. Journal of Land Use Science, 13(3), 325-343.

Zaehringer, J. G., Wambugu, G., Kiteme, B., \& Eckert, S. (2018). How do large-scale agricultural investments affect land use and the environment on the western slopes of Mount Kenya? Empirical evidence based on small-scale farmers' perceptions and remote sensing. Journal of Environmental Management, 213, 79-89.

\section{About the Author}

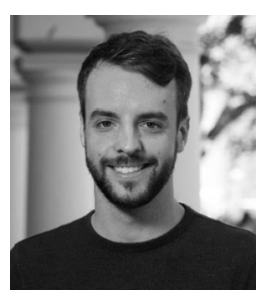

Koen Dekeyser works at the European Centre for Development Policy Managemen (ECDPM) on sustainable food systems and food governance as part of the Economic and Agricultural Transformation programme. Koen was a research fellow at the Centre for the Study of Governance Innovation and the National Centre of Excellence in Food Security, South Africa, following his doctorate in political economy at the University of Pretoria. He has experience working in South Africa, Mozambique, Kenya, Turkey, Indonesia, and Denmark. 